\title{
Podstawowe parametry głowic ultradźwiękowych oraz ich wpływ na jakość wykonywanych badań
}

\author{
Basic parameters of ultrasonic probes \\ and their impact on quality of ultrasonic examination
}

\section{Streszczenie}

W artykule opisano podstawowe parametry głowic ultradźwiękowych zdefiniowane w PN-EN 12668-2 oraz ASTM E 1065-08. Opisano typowe uszkodzenia głowic ultradźwiękowych, występujące podczas eksploatacji oraz przeanalizowano ich wpływ na podstawowe parametry głowic ultradźwiękowych. W dalszej kolejności pokazano w jaki sposób parametry głowic mogą wpływać na istotne aspekty badań ultradźwiękowych, w szczególności na wykrywalność, interpretację oraz ocenę wskazań. Omawiane zagadnienia zilustrowano praktycznymi przykładami pokazującymi wpływ parametrów głowic na wyniki badań.

Podkreślono znaczenie właściwego nadzoru nad stanem technicznym głowic ultradźwiękowych w całościowym systemie zapewnienia jakości badań ultradźwiękowych. Wskazano na konieczność prowadzenia okresowych kontroli głowic ultradźwiękowych podobnie jak ma to miejsce w odniesieniu do defektoskopów.

Słowa kluczowe: głowice ultradźwiękowe; parametry głowic ultradźwiękowych; uszkodzenia głowic ultradźwiękowych; nadzór nad wyposażeniem badawczym, badania ultradźwiękowe

\begin{abstract}
The article describes the basic characteristics of ultrasonic probes as defined in the international standards PN-EN 12668-2 and ASTM E 1065-08. It further describes the typical damages to ultrasonic probes in use and their effect on basic probe parameters. Then it shows how the probe parameters affect important aspects of ultrasonic testing, especially detection, interpretation and evaluation of indications. The discussed topics are illustrated with practical examples showing correlation between the probe parameters and examination results.

The paper emphasizes the importance of proper supervision of technical condition of ultrasonic probes in the overall quality assurance system of ultrasonic testing. It points out the necessity to conduct periodic checks of ultrasonic probes in the same way as it is done with ultrasonic flaw detectors.
\end{abstract}

Keywords: ultrasonic probes; parameters of ultrasonic probes; defects of ultrasonic probes; supervision of test equipment; ultrasonic testing

\section{Wstęp}

Ważnym elementem zapewnienia jakości badań nieniszczących prowadzonych przez specjalistyczną firmę lub laboratorium jest nadzór nad stosowanym wyposażeniem pomiarowym i badawczym. W przypadku badań ultradźwiękowych sprowadza się do nadzoru nad aparatami ultradźwiękowymi (defektoskopami, grubościomierzami), głowicami oraz wzorcami i próbkami odniesienia.

Zgodnie z obowiązującymi normami wszystkie wymienione elementy wyposażenia ultradźwiękowego powinny posiadać certyfikaty producenta potwierdzające ich zgodność z odpowiednimi normami. W szczególności defektoskopy powinny spełniać wymagania PN-EN 12668-1, zaś głowice PN-EN 12668-2. O ile jednak norma dotycząca aparatury ultradźwiękowej nakazuje coroczne sprawdzanie defektoskopów przez uprawnione laboratorium, o tyle norma dotycząca głowic wymaga jedynie wystawienia certyfikatu dla głowic nowych. Nie ma tutaj konieczności wykonywania corocznych badań okresowych. Obowiązkowe sprawdzenia głowic muszą być wykonywane jedynie w ramach uproszczonych kontroli operatorskich wykonywanych zgodnie z PN-EN 12668-3. Należy jednak zauważyć, że kontrole operatorskie dotyczą zasadniczo jedynie dwóch parametrów głowicy: środka oraz kąta wiązki. Pozostałe badania, obejmujące pomiar czułości, stosunku sygnału do szumu oraz szerokości impulsu dotyczą kompletnego systemu badawczego aparat - głowica i nie mogą być traktowane, jako weryfikacja parametrów samej głowicy. W sytuacji, gdy w laboratorium NDT wykorzystuje się kilka defektoskopów ultradźwiękowych i kilkanaście egzemplarzy głowic każda możliwa kombinacja aparatu ultradźwiękowego i głowicy powinna być periodycznie sprawdzana i odpowiednio dokumentowana. Jest to trudne do wykonania i w praktyce niestosowane. Zazwyczaj nadzoruje się pewien wybrany zestaw aparat-głowica, co oznacza, że każda ewentualna zmiana typu lub egzemplarza podłączonej do aparatu głowicy oznacza niezgodność w systemie zapewnienia jakości.

Dr Sławomir Mackiewicz - Instytut Podstawowych Problemów techniki PAN.

Autor korespondencyjny/Corresponding author. smackiew@ippt.gov.pl 
W praktyce oznacza to, że laboratoria badań nieniszczących wykazują znacznie większą dbałość o stan posiadanej aparatury ultradźwiękowej (defektoskopów i grubościomierzy) niż o stan stosowanych głowic. Jednak przy bliższej analizie procesu badania ultradźwiękowego nasuwa się wniosek, że w dobie cyfrowych defektoskopów ultradźwiękowych, prawdopodobieństwo uzyskania nieprawidłowych wyników badania z powodu niesprawności defektoskopu jest znacznie mniejsze niż z powodu niesprawności lub zużycia głowicy ultradźwiękowej. Z tego powodu okresowa kontrola parametrów głowic ultradźwiękowych powinna być prowadzona podobnie jak ma to miejsce w przypadku defektoskopów. Zgodnie z PN-EN 12668-2 wymaganie takie nie jest obligatoryjne, jednak można je wprowadzić w drodze uzgodnień pomiędzy zainteresowanymi stronami. Badanie okresowe głowic nie musi obejmować wszystkich parametrów wyszczególnionych w PN-EN ISO 12668-2 dla głowic nowych, lecz jedynie takie, które mają największe znaczenie dla jakości badań oraz mogą z dużym prawdopodobieństwem ulec pogorszeniu $w$ trakcie eksploatacji. Podejście takie jest obecnie stosowane w przemyśle lotniczym i powinno być rozszerzone na inne odpowiedzialne obszary badań ultradźwiękowych.

Celem niniejszego referatu jest pokazanie podstawowych zależności pomiędzy potencjalnymi uszkodzeniami głowic ultradźwiękowych a ich znormalizowanymi parametrami oraz praktycznymi skutkami dla badań ultradźwiękowych. Omawiane zagadnienia zilustrowano przykładami pokazującymi, w jaki sposób zmiany określonych parametrów głowic przekładają się na praktyczne aspekty badań. Przedstawiony materiał powinien ułatwić specjalistom nadzorującym badania ultradźwiękowe wdrożenie racjonalnych zasad nadzoru nad jakością stosowanych głowic ultradźwiękowych.

\section{Przegląd parametrów głowic ultradźwiękowych}

Pełne zestawy parametrów charakteryzujących głowice ultradźwiękowe określono w PN-EN 12668-2 [1] oraz ASTM E 1065-08 [2]. Istotną różnicą pomiędzy tymi normami jest fakt, że norma EN adresowana jest głównie do producentów głowic, podczas gdy norma ASTM dotyczy zarówno kontroli głowic przez producenta jak też badań głowic będących w eksploatacji. Ponadto norma [1] szczegółowo określa akceptowalne tolerancje dla poszczególnych parametrów, natomiast norma [2] pozostawia to do uzgodnienia pomiędzy zainteresowanymi stronami.

Norma PN-EN 12668-2 określa parametry, które powinien podawać producent w specyfikacji głowicy. Zestawy wymaganych parametrów różnią się w zależności od tego czy głowica przeznaczona jest do badań kontaktowych czy zanurzeniowych, czy jest głowicą normalną czy kątową, czy wytwarza fale podłużne czy poprzeczne, czy wreszcie jest głowicą pojedynczą, podwójną, skupiającą lub nieogniskowaną.

Część parametrów ma charakter czysto informacyjny. Są to takie dane jak nazwa producenta i typ głowicy, wymiary i waga, typ gniazda połączeniowego, materiał, kształt oraz rozmiary przetwornika, materiał i wymiary klina załamującego czy też materiał i grubość warstwy ochronnej.

Pozostałe parametry dotyczą parametrów funkcjonalnych głowic i muszą zostać określone przez producenta w drodze pomiarów lub obliczeń. Poniżej omówiono podstawowe parametry głowic, w szczególności takie, które mogą zmieniać się w trakcie eksploatacji i wpływać na jakość wykonywanych badań ultradźwiękowych.

Podstawowymi charakterystykami głowic ultradźwiękowych są kształt impulsu w dziedzinie czasu (tzw. impuls RF bez detekcji) oraz kształt jego widma w dziedzinie częstotliwości. Charakterystyki te stanowią podstawą do wyznaczenia kilku najważniejszych parametrów głowicy. Przykładowe charakterystyki uzyskane dla głowicy normalnej fal podłużnych pokazano na rysunku 1.

Wspomniane wcześniej normy dokładnie określają reflektory, jakie należy stosować w celu uzyskania impulsów referencyjnych charakteryzujących badane głowice. Ważne jest, aby w kolejnych badaniach stosować ten sam typ reflektora oraz jednakowe nastawy parametrów nadajnika oraz odbiornika aparatu ultradźwiękowego. Istotne znaczenie ma również typ oraz długość kabla łączącego głowicę z defektoskopem.
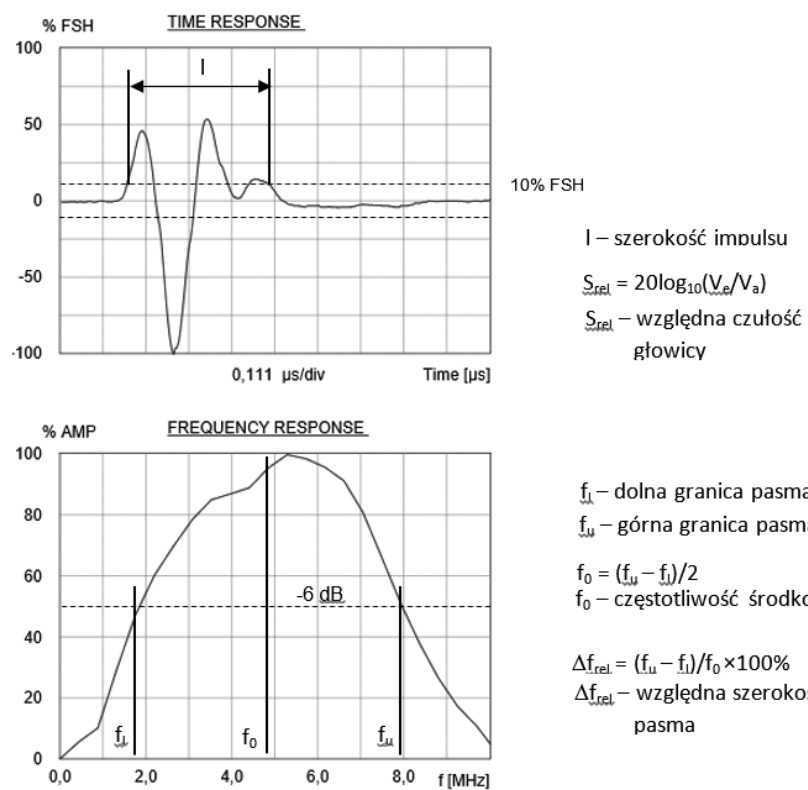

$\mathrm{f}_{\mathcal{L}}$ - dolna granica pasma $\mathrm{f}_{\mu}$ - górna granica pasma $f_{0}=\left(f_{\mu}-f_{j}\right) / 2$ $\mathrm{f}_{0}$ - częstotliwość środkowa $\Delta \mathrm{f}_{\text {rel }}=\left(\mathrm{f}_{\mathrm{u}}-\mathrm{f}_{\mathrm{l}}\right) / \mathrm{f}_{0} \times 100 \%$ $\Delta f_{\text {rel }}$ - względna szerokość pasma

Rys. 1. Kształt impulsu oraz widmo głowicy V201 wraz z oznaczeniem podstawowych parametrów wyznaczanych na podstawie tych charakterystyk

Fig. 1. Pulse shape and frequency spectrum of V201 probe with description of basic parameters derived from that characteristics

Na podstawie zarejestrowanego przebiegu czasowego impulsu określa się szerokość impulsu - I zdefiniowaną, jako odcinek czasu, na którym amplituda impulsu nie spada poniżej 10\% wartości maksymalnej. Norma [1] wymaga, aby wyznaczona szerokość impulsu nie odbiegała więcej niż o 10\% od wartości podanej w specyfikacji głowicy. Należy jednak zauważyć, że wymaganie to dotyczy głowic nowych, w przypadku głowic będących w eksploatacji PN-EN 12668-3 dopuszcza aż 50\% wzrost długości impulsu w stosunku do pomiaru podstawowego wykonanego przy tych samych nastawach i za pomocą tego samego aparatu ultradźwiękowego.

Na podstawie porównania napięcia peak-to-peak impulsu referencyjnego - $\mathrm{V}_{\mathrm{e}}$ oraz impulsu nadawczego - Va wyznacza się tzw. względną czułość głowicy - $\mathrm{S}_{\text {rel. }}$ Parametr ten charakteryzuje ogólną sprawność głowicy w przetwarzaniu impulsów elektrycznych na ultradźwiękowe i odwrotnie. Zgodnie z normą [1] wartość tego parametru nie powinna odbiegać od wartości podanej w specyfikacji o więcej niż $\pm 3 \mathrm{~dB}$.

Amplitudy napięć $V_{e}$ i $V_{a}$ należy wyznaczać za pomocą oscyloskopu cyfrowego bezpośrednio na zaciskach głowicy tj. przed wzmocnieniem oraz filtrowaniem impulsów w układzie odbiorczym aparatu ultradźwiękowego. W przypadku niemożności wyznaczenia parametru $S_{\text {rel }}$ można zastępczo wyznaczać parametr Absolute Gain (wzmocnienie absolutne) zdefiniowany w normie ASTM [2] i mający ścisły związek z czułością głowicy. Wyznaczanie tego parametru nie wymaga stosowania osobnego układu pomiarowego 
z oscyloskopem cyfrowym i polega na określeniu wzmocnienia defektoskopu, przy którym impuls referencyjny głowicy osiąga pełną wysokość ekranu (100\% FSH). W odróżnieniu od czułości względnej głowicy $S_{\text {rel }}$ tak określony parametr będzie zależał od defektoskopu ultradźwiękowego (typu a nawet egzemplarza) oraz ustawienia wielu jego parametrów (rodzaju i energii impulsu nadawczego, impedancji nadajnika, filtrów odbiornika). Może zatem służyć jedynie do pomiarów porównawczych prowadzonych za pomocą tego samego układu pomiarowego i przy tych samych ustawieniach. W przypadku badań tego samego typu głowic (a ściślej głowic o jednakowych parametrach elektrycznych) różnica wartości wzmocnień absolutnych będzie odpowiadać różnicy względnych czułości $S_{\text {rel }}$ tych głowic.

$\mathrm{Na}$ podstawie kształtu widma impulsu referencyjnego wyznacza się dwa inne kluczowe parametry głowicy: częstotliwość środkową - $\mathrm{f}_{0}$ oraz względną szerokość pasma - $\Delta_{\text {frel }}$.

Częstotliwość środkową, zwaną też częstotliwością podstawową głowicy, wyznacza się ze wzoru:

$$
f_{0}=\left(f_{u}-f_{l}\right) / 2
$$

gdzie:

$\mathrm{f}_{\mathrm{u}}$ - górna częstotliwość graniczna pasma głowicy przy $6 \mathrm{~dB}$ spadku

$\mathrm{f}_{\mathrm{l}}$ - dolna częstotliwość graniczna pasma głowicy przy $6 \mathrm{~dB}$ spadku

Zgodnie z normą [1] częstotliwość podstawowa głowicy nie powinna odbiegać od wartości nominalnej podanej w specyfikacji głowicy o więcej niż $\pm 10 \%$.

Należy zauważyć, że norma ASTM [2], oprócz częstotliwości środkowej, definiuje także częstotliwość maksimum widma impulsu $-f_{p}$. Różnica między tymi częstotliwościami stanowi miarę asymetrii pasma przenoszenia głowicy i w niektórych przypadkach może być użyta do diagnozowania jej stanu technicznego.

Względna szerokość pasma głowicy $-\Delta f_{\text {rel }}$ wyznaczana jest ze wzoru:

$$
\left.\Delta f_{r e l}=\left[\left(f_{u}-f_{l}\right) / 2\right)\right] 100 \%
$$

Względna szerokość pasma jest parametrem, który charakteryzuje stopień wytłumienia drgań przetwornika głowicy przez przylegającą masę tłumiącą, badany materiał oraz obwody elektryczne aparatu ultradźwiękowego. Ponieważ jej wartość silnie zależy od rezystancji wewnętrznej nadajnika oraz charakterystyki częstotliwościowej odbiornika pomiar $\Delta_{\text {frel }}$ powinien być dokonywany w powtarzalnych warunkach, najlepiej przy zastosowaniu tego samego zestawu pomiarowego. Zgodnie z normą [1] względna szerokość pasma głowicy nie powinna odbiegać od wartości nominalnej o więcej niż $\pm 15 \%$.

W przypadku głowic kątowych ważnymi parametrami, które mogą zmieniać się w trakcie eksploatacji są środek głowicy oraz kąt głowicy. Ponieważ, w zależności od nasilenia prowadzonych prac oraz chropowatości badanych powierzchni, parametry te mogą zmieniać się w bardzo różnym tempie, ich kontrola powinna być prowadzona na bieżąco przez operatora. W niektórych przypadkach, przy niesymetrycznym ścieraniu się klina lub linii opóźniającej głowicy może zmienić się także kąt zboczenia wiązki.

Szereg parametrów wyspecyfikowanych w normie [1] dotyczy charakterystyki geometrycznej wiązki ultradźwiękowej wytwarzanej przez głowicę. W szczególności są to rozbieżności wiązki w dwóch wzajemnie prostopadłych płaszczyznach a także odległość ogniskowa oraz rozmiary ogniska w przypadku głowic skupiających. Parametry te zdeterminowanie są głównie przez rozmiary geometryczne elementów głowicy oraz dokładność jej wykonania i montażu.
Zasadniczo, nie powinny one ulegać zmianom w trakcie eksploatacji, o ile tylko nie ulegnie zmianie częstotliwość podstawowa oraz pasmo przenoszenia głowicy.

Parametry elektryczne głowicy (pojemność statyczna oraz charakterystyka impedancyjna) mogą zmienić się wskutek eksploatacji jednak ich wpływ na wyniki badania ultradźwiękowego jest zawsze pośredni, tj. przejawia się przez zmiany przebiegu czasowego oraz widma impulsu głowicy. Nie ma więc konieczności mierzenia tych parametrów podczas okresowej kontroli głowic ultradźwiękowych.

\section{Uszkodzenia głowic oraz ich wpływ na mierzone parametry}

Podstawą dla wprowadzenia racjonalnej kontroli okresowej głowic ultradźwiękowych musi być zrozumienie zależności, jakie zachodzą między typowymi uszkodzeniami głowic podczas eksploatacji a ich parametrami funkcjonalnymi. W dalszej kolejności należy przeanalizować wpływ określonych parametrów głowicy na praktyczne aspekty badania ultradźwiękowego.

Biorąc pod uwagę typową konstrukcję głowic ultradźwiękowych opartych na przetwornikach piezoelektrycznych można wyróżnić kilka typowych przyczyn ich eksploatacyjnych uszkodzeń i degradacji.

W przypadku głowic kątowych jest to w pierwszym rzędzie ścieranie się czoła klina załamującego prowadzące do zmiany środka oraz kąta głowicy. Szczególnie niebezpieczne jest nierównomierne ścieranie się klina prowadzące do zmiany kąta załamania głowicy. Przykładowo, dla głowicy o kącie nominalnym $70^{\circ}$ niewielka zmiana kąta powierzchni czołowej klina w kierunku podłużnym wynosząca $1^{\circ}$ prowadzić będzie do zmiany kąta głowicy o 2,2 ${ }^{\circ}$ co przekracza limit tolerancji określony w normach [1] i [3].

Typową przyczyną uszkodzeń głowic normalnych jest odklejanie się oraz pękanie warstwy ochronnej przetwornika głowicy. Przykłady głowic z tego rodzaju uszkodzeniami pokazano na rysunku 2.
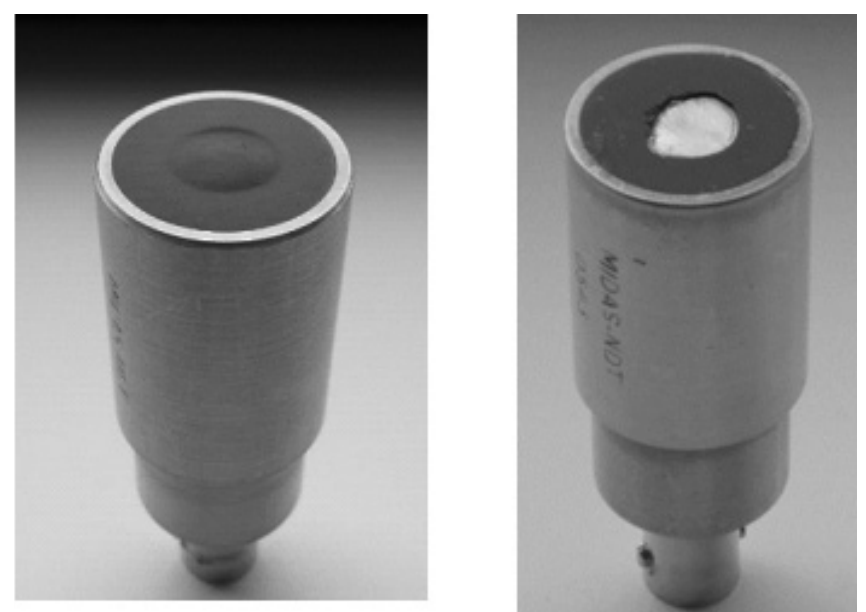

Rys. 2. Głowice do badań zanurzeniowych z uszkodzoną warstwą ochronną przetwornika

Fig. 2. Immersion probes with defects in the transducer protective layer

Ten typ uszkodzeń głowicy powoduje osłabienie transmisji fali ultradźwiękowej z przetwornika do materiału badanego, co w pierwszym rzędzie wpływa na obniżenie czułości względnej głowicy $-S_{\text {rel }}$.

W przypadku odklejenia się przetwornika od masy tłumiącej najważniejszą zmianą w parametrach głowicy będzie znaczne zmniejszenie się względnej szerokości pasma - $\Delta_{\text {frel }}$ oraz zwiększenie szerokości impulsu - I. Jednocześnie, 
czułość względna głowicy może ulec pewnemu podwyższeniu. Efekty te będą szczególnie widoczne w przypadku głowic szerokopasmowych.

Przy częściowym odklejeniu się przetwornika od masy tłumiącej może dojść do zniekształcenia widma głowicy polegającego na pojawieniu się dwóch maksimów. Zgodnie z wymaganiami normy [1] spadek amplitudy widma pomiędzy sąsiadującymi maksimami nie może przekroczyć wartości $3 \mathrm{~dB}$.

W przypadku głowic kątowych przyczyną pogorszenia się właściwości użytkowych głowicy może być również odklejenie się przetwornika od klina załamującego. Objawi się to głównie przez znaczne obniżenie czułości względnej głowicy - $\mathrm{S}_{\text {rel. }}$

W przypadku głowic wąskopasmowych, wyposażonych w cewkę indukcyjną przyczyną uszkodzenia głowicy może być odłączenie się lub przerwanie obwodu cewki. Objawi się to jako obniżenie czułości względnej głowicy $S_{\text {rel }}$ przy jednoczesnym zwiększeniu względnej szerokości pasma. W niektórych przypadkach może zmienić się częstotliwość podstawowa głowicy $-f_{0}$.

W przypadku długotrwałej eksploatacji lub częstego wykonywania badań w podwyższonych temperaturach przetwornik piezoelektryczny głowicy może ulec częściowej depolaryzacji. Spowoduje to obniżenie współczynnika sprzężenia elektromechanicznego ceramiki piezoelektrycznej przetwornika i w konsekwencji spadek czułości względnej głowicy - $S_{\text {rel. }}$ W tym przypadku szerokość pasma głowicy oraz szerokość impulsu pozostaną bez zmian.

Jak wynika z przeprowadzonego przeglądu tylko niektóre z potencjalnych uszkodzeń głowic mogą zostać wykryte w ramach bieżącej kontroli operatorskiej. Dotyczy to np. zmiany kąta i/lub środka głowicy. Trudne do wykrycia są natomiast uszkodzenia zachodzące stopniowo, niewidoczne na zewnątrz i niepowodujące nagłego pogorszenia parametrów funkcjonalnych głowic. W przypadku wieloletniej eksploatacji uszkodzenia takie mogą znacząco wpłynąć na jakość wykonywanych badań ultradźwiękowych. Jedynie sukcesywna kontrola okresowa podstawowych parametrów głowic może skutecznie wykryć i wyeliminować tego rodzaju problemy.

\section{Wpływ zmian parametrów głowicy na wyniki badań}

Ocena stanu technicznego głowic w ramach kontroli okresowej opierać się może na tolerancjach określonych w normie [1] bądź też bazować na indywidualnych kryteriach akceptacji ustalanych przez zainteresowane strony.

W celu racjonalnego ustalenia takich kryteriów należy przeanalizować podstawowe zależności, jakie zachodzą między zmianami parametrów głowic a istotnymi aspektami badań ultradźwiękowych.

Jednym z podstawowych parametrów głowicy jest jej częstotliwość podstawowa - $\mathrm{f}_{0}$. Norma [1] dopuszcza $10 \%$ odchylenie tego parametru od wartości nominalnej. Rozważmy, w jaki sposób niekontrolowana zmiana tej częstotliwości może wpłynąć na wyniki badania. Z praktycznego punktu widzenia najważniejszą negatywną konsekwencją takiej niezgodności będzie unieważnienie krzywych DGS generowanych przez defektoskop dla danego typu głowicy. Oprogramowanie defektoskopu oblicza krzywe DGS przy założeniu częstotliwości nominalnej wybranej głowicy, zaś jej ewentualna niezgodność skutkuje nieprawidłowym obliczeniem długości pola bliskiego i wygenerowaniem krzywej DGS niezgodnej z faktycznym przebiegiem zależności DGS dla danej głowicy.
W celu ilustracji tego problemu rozpatrzymy przykład szeroko stosowanej głowicy kątowej fal poprzecznych o częstotliwości nominalnej $4 \mathrm{MHz}$ i wymiarach przetwornika $8 \times 9$ mm. Załóżmy, że wskutek uszkodzenia eksploatacyjnego częstotliwość podstawowa głowicy zmniejszyła się o 15\% (tj. do 3,4 MHz). Wskutek tego długość pola bliskiego głowicy uległa skróceniu i rzeczywista zależność DGS będzie różnić się do zależności obliczonej przez aparat. Różnicę miedzy tymi zależnościami pokazano na rysunek 3.

\section{$\mathrm{ZO}=100 \mathrm{~mm}, \quad f=4 \mathrm{MHz}, \quad a \times b=8 \times 9 \mathrm{~mm}$}

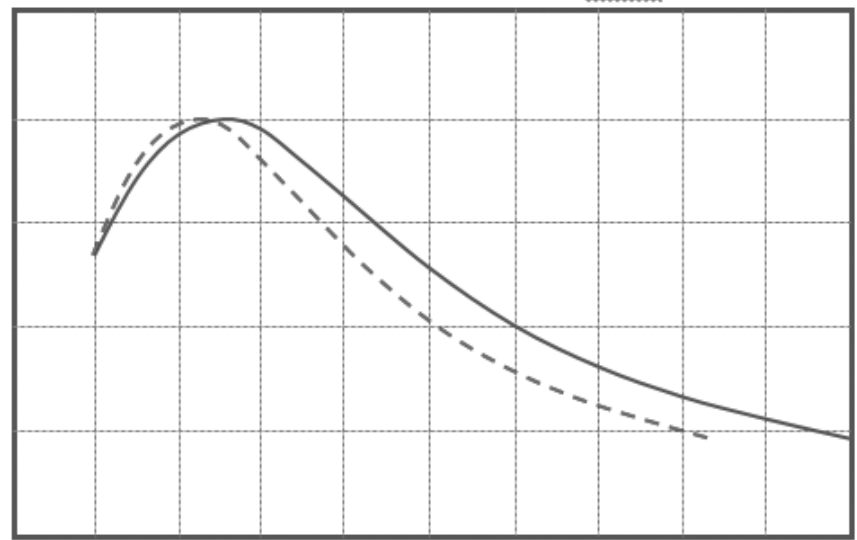

Rys. 3. Krzywa DGS obliczona przez aparat ultradźwiękowy dla miniaturowej głowicy kątowej o częstotliwości nominalnej $f=4 \mathrm{MHz}$ (linia ciągła) oraz rzeczywista zależność DGS dla głowicy o częstotliwości obniżonej o 15\% (linia przerywana).

Fig. 3. DGS curve calculated by flaw detector for miniature angle probe with nominal frequency of $4 \mathrm{MHz}$ (solid line) as compared to the actual DGS dependence for the probe with actual frequency reduced by $15 \%$ (dashed line)

Rzeczywista zależność DGS dla rozważanej głowicy przebiega, w dużej części zakresu pomiarowego, ok. $2 \mathrm{~dB}$ poniżej krzywej teoretycznej obliczonej przez aparat. W przypadku prowadzenia oceny wskazań ultradźwiękowych według tej krzywej ich poziomy echa będą systematycznie zaniżane o ok. 2 dB. W przypadku większego odstępstwa częstotliwości podstawowej od wartości nominalnej skala popełnianego błędu będzie oczywiście odpowiednio większa.

W celu przeanalizowania wpływu względnej szerokości pasma głowicy - $\Delta_{\text {frel }}$ rozpatrzmy charakterystyki częstotliwościowe dwóch głowic kątowych o podobnych parametrach nominalnych, tj. starszego typu głowicy $4 \mathrm{~T}^{\circ} 0^{\circ} 10 \mathrm{C}$ firmy INCO oraz nowoczesnej głowicy ABC 0470 firmy KeyYu.

Częstotliwości podstawowe obu głowic są prawie jednakowe (4 MHz), jednak szerokości pasma różnią się zasadniczo. Dla głowicy $4 \mathrm{~T}^{\circ} 0^{\circ} 10 \mathrm{C}$ względna szerokość pasma wynosi tylko $17,9 \%$ natomiast dla głowicy $A B C 0470$ jest to $44,2 \%$.

Większa szerokość pasma w dziedzinie częstotliwości przekłada się na mniejszą szerokość impulsu w dziedzinie czasu. Odpowiednie przebiegi czasowe impulsów RF dla obu głowic pokazano na rysunku 5. Dla głowicy $4 \mathrm{~T} 70^{\circ} 10 \mathrm{C}$ normowa szerokość impulsu referencyjnego wynosi 2,26 $\mu \mathrm{s}$, natomiast dla głowicy $A B C 0470$ jest to zaledwie 0,97 $\mu \mathrm{s}$.

Mniejsza szerokość impulsu głowicy powoduje, że układ badawczy wykazuje wyższą rozdzielczość w kierunku osi wiązki. Oznacza to możliwość lepszego rozróżniania nieciągłości położonych w zbliżonej odległości od głowicy a także dokładniejszego wyznaczania położeń i rozmiarów wad. Wyższa rozdzielczość czasowa głowic ułatwia także odróżnianie ech kształtu od wskazań wad jak również pozwala na wykonywanie dokładniejszych pomiarów grubości.

Jakkolwiek szerokość pasma i długość impulsu są bardzo ważnymi charakterystykami głowicy musi im towarzyszyć odpowiednio duża czułość głowicy wyrażona parametrem 
- Srel. Impulsy wskazań ultradźwiękowych muszą być nie tylko krótkie, ale też odpowiednio wysokie, tak aby wyraźnie wychodziły ponad poziom szumów.

W przypadku dwóch porównywanych głowic nie wyznaczono bezpośrednio czułości względnej - Srel a jedynie wzmocnienia absolutne przy tych samych ustawieniach aparatu ultradźwiękowego. Wynosiły ono odpowiednio 58,3 $\mathrm{dB}$ dla głowicy $4 \mathrm{~T} 70^{\circ} 10 \mathrm{C}$ oraz $33,9 \mathrm{~dB}$ dla głowicy $\mathrm{ABC}$ 0470. Oznacza to, że przybliżona różnica czułości względnych tych głowic wynosiła ok. $24 \mathrm{~dB}$ na korzyść głowicy typu ABC 0470. Stwierdzona różnica czułości może wynikać zarówno z procesów degradacyjnych, które zaszły w głowicy
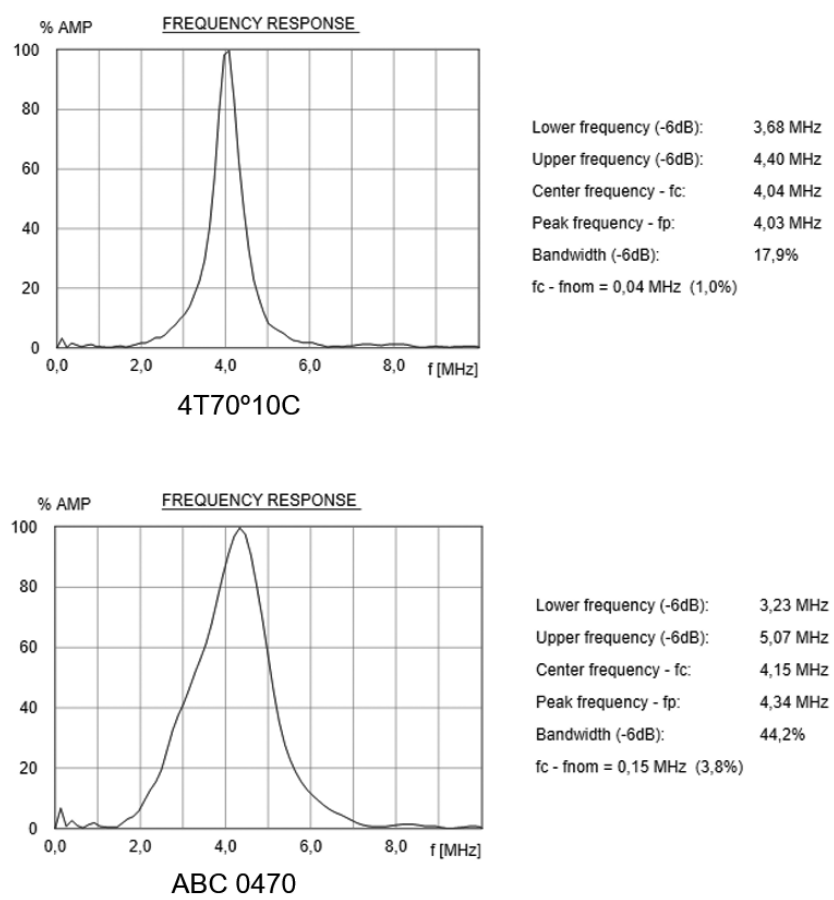

Lower frequency (-6dB):Upper frequency (-6dB): $\quad 5,07 \mathrm{MHz}$ Center frequency - $\mathrm{fC}: \quad 4,15 \mathrm{MHz}$ Peak frequency - $\mathrm{fp}: \quad 4,34 \mathrm{MHz}$ Bandwidth $(-6 \mathrm{~dB})$ : $44,2 \%$ fc - fnom $=0,15 \mathrm{MHz}(3,8 \%)$

Rys. 4. Charakterystyki częstotliwościowe głowic kątowych $4 \mathrm{~T} 70^{\circ} 10 \mathrm{C}$ oraz $\mathrm{ABC} 0470$ o podobnych parametrach nominalnych ale różnej szerokości pasma

Fig. 4. Frequency spectra of angle probes $4 T 70^{\circ} 10 \mathrm{C}$ and $\mathrm{ABC} 0470$ having similar nominal parameters but different bandwidths

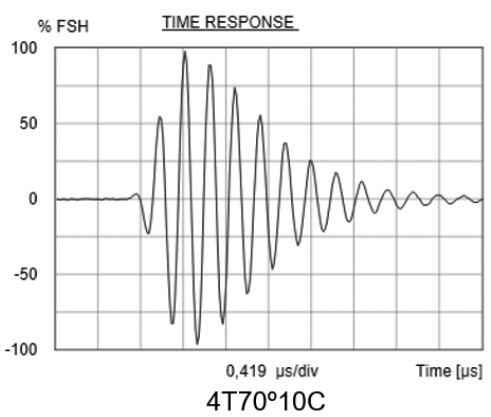

Absolute gain (100\% FSH): $\quad 58,3 \mathrm{~dB}$ Waveform duration (-20dB): $\quad 2,263 \mu \mathrm{s}$

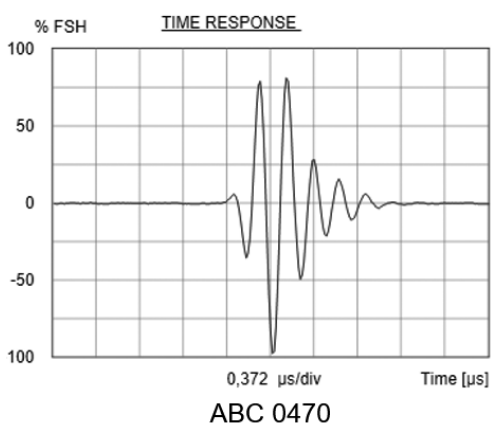

Absolute gain (100\% FSH): $\quad 33,9 \mathrm{~dB}$ Waveform duration $(-20 \mathrm{~dB}): \quad 0,968 \mu \mathrm{s}$

Rys. 5. Kształty impulsów RF głowic kątowych $4 T 70^{\circ} 10 \mathrm{C}$ oraz $\mathrm{ABC} 0470$ Fig. 5. Pulse shapes of angle probes $4 T 70^{\circ} 10 \mathrm{C}$ and $A B C 0470$ $4770^{\circ} 10 \mathrm{C}$ w wyniku wieloletniej eksploatacji jak również z faktu, że ceramika piezoelektryczna stosowana w obecnie produkowanych głowicach posiada lepsze parametry niż ceramika stosowana w latach 80-tych. Najprawdopodobniej przyczyniły się do tego oba wymienione fakty.

Niezależnie od tego najważniejsze dla prowadzonych rozważań jest stwierdzenie, w jakim stopniu różnica czułości oraz szerokości pasma obu głowic przekłada się na praktyczne aspekty badań ultradźwiękowych. W tym celu obie głowice ustawiono na wzorcu nr 2 tak, aby uzyskać zmaksymalizowane echo od powierzchni cylindrycznej R25. Następnie zwiększono wzmocnienie tak, aby uzyskać czułość badania odpowiadająca reflektorowi odniesienia o średnicy DDSR $=1,5 \mathrm{~mm}$. Obrazy ekranu uzyskane po wykonaniu tej procedury dla obu testowanych głowic pokazano na rysunku 6.

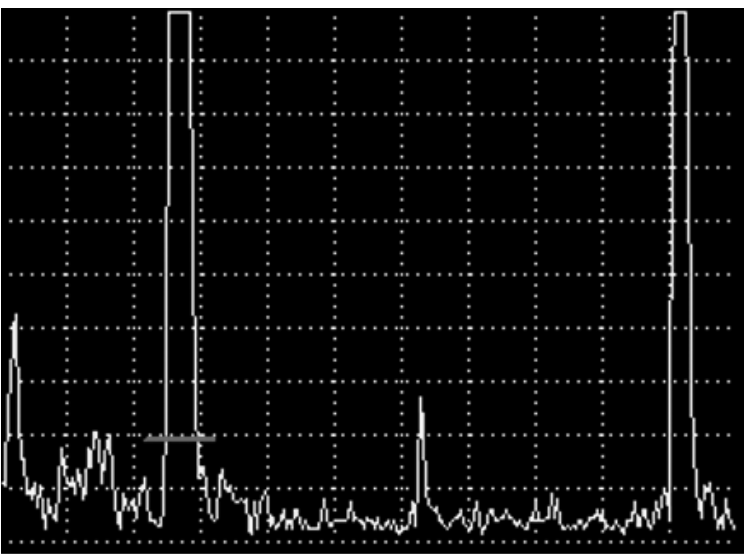

$4 \mathrm{~T} 70^{\circ} 10 \mathrm{C}$

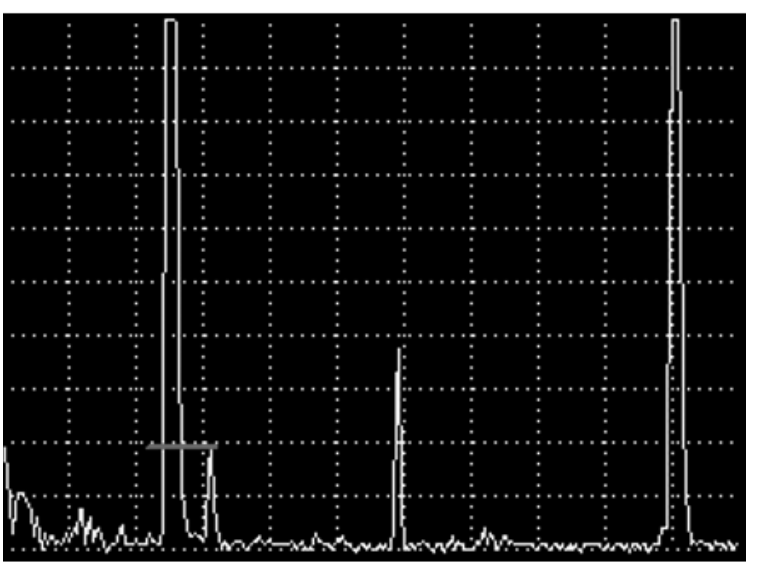

$\mathrm{ABC} 0470$

Rys. 6. Zobrazowania ultradźwiękowe typu A uzyskane głowicami $4 \mathrm{~T} 70^{\circ} 10$ oraz $\mathrm{ABC} 0470$ na wzorcu nr 2 po nastawieniu jednakowej czułości badania

Fig. 6. A-scans obtained with $4 \mathrm{~T} 70^{\circ} 10 \mathrm{C}$ and $\mathrm{ABC} 0470$ probes on $\mathrm{V} 1$ calibration block after the same sensitivity setting

Zgodnie z oczekiwaniami zobrazowanie typu A uzyskane głowicą $4 \mathrm{~T}^{\circ} 0^{\circ} 10$ cechuje się znacznie wyższym poziomem szumów niż zobrazowanie uzyskane głowicą ABC 0470. Dużo trudniej zaobserwować na nim mniejsze echa, które interferują z szumami i mogą być przeoczone w prowadzonym badaniu. Widoczna jest również wyraźna różnica w szerokości impulsów ultradźwiękowych odbitych od powierzchni wzorca. Przykład ten pokazuje praktyczną różnicę w prowadzeniu badań ultradźwiękowych przy użyciu głowic, ogólnie rzecz biorąc sprawnych, lecz wyraźnie różniących się co do niektórych parametrów funkcjonalnych. Dotyczy to w szczególności takich parametrów jak względna szerokość pasma - $\Delta_{\text {frel }}$ oraz względna czułość $-S_{\text {rel. }}$. 


\section{Podsumowanie}

Z przedstawionej analizy i przykładowych rezultatów badań wynika jednoznacznie, że parametry funkcjonalne głowic ultradźwiękowych, a w szczególności ich niekontrolowane zmiany mają bardzo istotny wpływ na jakość prowadzonych badań ultradźwiękowych. Wpływają one na prawidłowość nastawiania czułości badania, prawidłowość oceny wskazań oraz dokładność określania położeń i rozmiarów wad. Mają także bardzo istotny wpływ na łatwość prowadzenia badań oraz interpretacji wskazań przez operatorów.

Zapewnienie odpowiedniego nadzoru nad jakością stosowanych głowic jest bardzo ważnym aspektem zapewnienia jakości całego systemu badań ultradźwiękowych i powinno być traktowane na równi z nadzorem nad jakością defektoskopów ultradźwiękowych. Oznacza to, że należy prowadzić zarówno bieżące kontrole operatorskie zgodnie z wymaganiami PN-EN 12668-3 jak również laboratoryjne badania okresowe wykonywane w oparciu o wymagania PN-EN 12668-2 lub ASTM E 1065-08.

Badania okresowe powinny obejmować, jako minimum: wyznaczenie kształtu impulsu RF głowicy oraz jego widma a także pomiar takich parametrów jak częstotliwość podstawowa - $f_{0}$, względna szerokość pasma - $\Delta_{\text {frel }}$ oraz względna czułość $-S_{\text {rel. }}$ Kryteria oceny tych parametrów można określić na podstawie wymagań PN-EN 12668-2 lub też uzgodnić w porozumieniu z zainteresowanymi stronami.

Proponowane podejście jest obecnie stosowane w przemyśle lotniczym i należy oczekiwać, że w najbliższych latach rozszerzy się na inne sektory i obszary zastosowań badań ultradźwiękowych.

\section{Literatura}

[1] PN-EN 12668-2:2010 Badania nieniszczące - Charakteryzowanie i weryfikacja aparatury ultradźwiękowej - Część 2: Głowice.

[3] PN-EN 12668-3 Badania nieniszczące - Charakteryzowanie i weryfikacja aparatury ultradźwiękowej - Część 3: Aparatura kompletna.

[2] ASTM E 1065-08 Standard Guide for Evaluating Characteristics of Ultrasonic Search Units. 